\title{
MĀORI KNOWLEDGE AND CONSUMER TRIBES
}

\author{
Tyron Love* \\ Jörg Finsterwalder ${ }^{\dagger}$
}

Alastair Tombs ${ }^{\ddagger}$

\begin{abstract}
This paper explores an agenda for consumer behaviour research as it relates to tribal consumerism. It is argued that while the international consumer behaviour research field is inspired by Indigenous knowledges, the quality of research will be relatively poor and unconvincing unless Indigenous researchers and voices make their way into those conversations. We argue for greater plurality through Indigenous participation in consumer behaviour research, and we challenge business schools to realise their accountability.
\end{abstract}

\section{Keywords}

Māori knowledges, consumer behaviour research, consumer tribes

A number of commentators have drawn our attention to the problematic nature of research for Māori and Indigenous people (see, e.g., Bishop, 1996; Metge, 1995; L. T. Smith, 2012). Business research is particularly notable in this regard due to a history of ideas which have prioritised the corporate elite and the exploitation of resources and workers through questionable practices grounded in the domination and manipulation of workers and the suppression of voices. It is these ideas which Māori and other Indigenous researchers have sought to challenge, and readers of this journal will be well aware of the debates.

* Te Atiawa. Associate Dean Māori and Senior Lecturer, Department of Management, Marketing and Entrepreneurship, University of Canterbury, Christchurch, New Zealand. Email: tyron.love@canterbury.ac.nz

+ Associate Professor, UC Business School, University of Canterbury, Christchurch, New Zealand.

‡ Senior Lecturer, UQ Business School, University of Queensland, Brisbane, Australia.

DOI: 10.20507/MAIJournal.2018.7.1.4 
Over the past decade in Aotearoa New Zealand we have seen a growing body of literature at the intersection of Māori and business knowledges (Haar \& Brougham, 2011; Haar \& Brougham, 2013; Haar, Roche, \& Taylor, 2012; Kuntz, Nāswall, Beckingsale, \& Macfarlane, 2014; Ruwhiu \& Cone, 2013; Ruwhiu \& Elkin, 2016; Spiller, Erakovic, Henare, \& Pio, 2011; Spiller, Pio, Erakovic, \& Henare, 2011). Important conversations deal with concepts drawing attention to shortcomings as well as opportunities and prospects for Māori, as both business practitioners and researchers. In this short commentary we draw attention to an under-researched field of Māori business: consumer behaviour. In particular, we put forward the idea that Māori knowledge could potentially redefine the boundaries in a particularly hot field of consumer behaviour research, that of consumer tribes.

A consumer tribe is a consumer-driven group based on shared values, passions and beliefs (Cova \& Cova, 2002; Mitchell \& Imrie, 2011). Some examples of consumer tribes are dedicated communities of "pet lovers", "runners", "surfers" and "organic foodies". They exist through collective social interactions focused on shared experiences and emotions facilitated through any number of brands, products, services or activities (Cova \& Cova, 2002; Goulding, Shankar, \& Canniford, 2013). They have also been defined as collective groups whose members share some enthusiasm for, and knowledges of, a particular consumptionrelated activity (Armstrong \& Hagel, 1996; Kozinets, 1999, 2006). Several recently published business and consumer books highlight the popularity surrounding consumer tribes in practice and research: Susanne Currid's Build Your Tribe: The New Marketing Manifesto for Restaurants, Bars and Cafés (2013); Seth Godin's Tribes: We Need You to Lead Us (2008); Dave Logan, John King and Halee Fischer-Wright's (2008) Tribal Leadership: Leveraging Natural Groups to Build a Thriving Organization and Brendan Richardson's Tribal
Marketing, Tribal Branding (2013), to name a few.

There are some variations of consumer tribes; e-tribe, for example, describes a virtual community based on collective consumption activities (Kozinets, 1999). The term neo-tribe refers to a collective consumer-orientated association among individuals (Bennett, 1999; Maffesoli, 1996) and is defined similarly to consumer tribe. Members of a consumer tribe share common values often based on social or ideological perspectives rather than just the shared use of, or value derived from sharing, a common product or service (Holzweber, Mattsson, \& Standing, 2015). It is the shared experiences and ability to engage collective social interactions that differentiate the contemporary consumer tribe from a group of shoppers who happen to purchase similar items.

The term consumer tribe has been used as a metaphor for the structure of consumption communities. However, few researchers (Cova, 1997, and Maffesoli, 1996, are exceptions) offer explanations as to why the term tribe fits the mould for the purposes of explaining a group of consumers drawn together by a common interest. Some authors use the term assuming the reader has some tacit knowledge of what constitutes a tribe. As Cova, Kozinets and Shankar (2007) have noted, what is "most alluring of all is the notion that by calling a phenomenon 'tribal' we have somehow explained it" (p. 4). Others have emphasised the term is simply a "deracinated metaphor" (O'Reilly, 2012, p. 345). Some suggest the consumer tribe simply reflects an inherently fragile, ephemeral and fluid form of connectedness (Cova et al., 2007; Riley, Griffin, \& Morey, 2010; Maffesoli, 1996).

Mitchell and Imrie (2011) argue that visualising consumer tribes provides marketers with a structure for identifying the often elusive individual consumer and provides the opportunity for businesses to connect with what might otherwise be viewed as a fragmented consumer base. This is useful because ultimately 
consumers have a need to satisfy feelings of social solidarity and to create cultural worlds (albeit temporary) through seeking community in their consumption (Belk \& Costa, 1998; Kozinets, 2002). Thinking about consumersas-tribes allows marketers to view consumers on consumers' terms (Mitchell \& Imrie, 2011).

Within the field of consumer behaviour research, theorists remind us that the role of business is to provide a platform that facilitates consumers' ability to make use of the collective wisdom of a group of people in order to enhance the value consumers derive from the use of, or association with, particular products. As such, businesses must work to assist consumers' cocreation of value, whether this be used as instant gratification of some need/want or whether it is stored as a collective resource that can be shared if, and when, required by all the members of that group. A business that is unresponsive or unsympathetic to the needs of a group can easily be sidelined, despite their product offering being suitable for the members or activities of that group. This ultimately has to do with understanding the concept of exchange.

For some time now certain Western business ways of thinking about exchange have had an influence on how actors and institutions can and should be viewed in relation to one another and their embeddedness in the business environment (e.g., Flood \& Jackson, 1991; Giddens, 1984; Luhmann, 1982; Midgley, 2000; Parsons, 2007; Simmel, 1950; Vānninen, Pereira-Querol, \& Engestrōm, 2015). Some researchers have sought to understand how value is co-created within market communities and the influence that context plays in framing the exchange of goods and services (Chandler \& Vargo, 2011). The basic contention is that the interconnectedness of the individual and the market shows that the use and exchange of resources to co-create value will differ depending on the level of interaction determined by a specific context.

Chandler and Vargo (2011) suggest that this context can be described as consisting of three levels: micro, meso and macro. These are defined by the dyadic and therefore direct interactions that occur between two actors (micro level), the triadic (direct and indirect) interactions between three actors (meso level) and the more complex interactions between triads (macro level), both direct and indirect, but where the latter eventuate when actors are not directly connected but interact via other actors. Further, a time perspective has been introduced that relates to the evolution of systems (Chandler \& Vargo, 2011). Using this perspective, the term ecosystem has been introduced as a "relatively self-contained, self-adjusting system of resource-integrating actors connected by shared institutional arrangements and mutual value creation through service exchange" (Vargo \& Lusch, 2016, pp. 10-11).

Such an approach is similar to Bronfenbrenner's (1977) “ecology of human development". Bronfenbrenner proposes a multilevel ecological environment made up of micro, meso, exo and macro levels. The micro level depicts relationships that occur between the person and the environment within an immediate setting (e.g., family, school, etc.). The meso level describes interrelationships among major settings that contain the person (i.e., interactions between family, workplace, peer groups, etc.). The exo level extends meso contexts, as formal and informal interactions may not contain the individual but do have an impact on them. Finally, the macro level holds the overarching institutional patterns of the culture or subculture. Bronfenbrenner (1977) also adds a temporal dimension (a "chrono" perspective) to this approach that accounts for the changes in interaction over time.

These researchers provide frameworks which link contexts, markets and value co-creation to the interconnections that occur within different levels of society. The surface-level relevance of seeing consumers as interconnected networks of people for the purposes of marketing to them seems apparent. What hasn't been debated is the complexity that lies within these groups 
of consumers known as "tribes". The obvious question at this point is how Māori and Indigenous ways of knowing can inform the debate and tease out some of the complexity. Obvious, because Māori and Indigenous peoples have access to intricate tribal knowledges that we believe outperform contemporary consumer behaviour research dialogues at present.

Māori and non-Māori researchers have written about traditional and contemporary Māori institutions and structures in ways that are suggestive of the tribe-based structures we have introduced. Stories of early Māori society tell of migrations from Polynesia around the 13th century in waka (Buck, 1950/1962; Firth, 1929/2011; Tarakawa \& Smith, 1894; Walker, 1990). They tell of iwi sometimes identifiable by territorial geographic boundaries of significant social, cultural and economic importance (Barlow, 1994); hapū often responsible for controlling a defined area of tribal territory accessing resources from the seashore or streams and rivers (Firth, 1929/2011; Walker, 1990); and whānau providing a workforce in shared activities such as hunting, fishing and gathering. From an institutional perspective, Māori society has been cast as interlinking individual with group, whereby "the rights of individuals, or the hurts they may suffer when their rights were abused, were indivisible from the welfare of the whānau, the hapū, the iwi. Each had reciprocal obligations found in a shared genealogy, and a set of behavioural precedents established by common tīpuna" (Jackson, 1990, p. 32).

With these notions of institutions and institutional arrangements also come places: kāinga, pā, marae, wharenui and pātaka, to name some of the more common (Buck, 1950/1962). These were, and are, social spaces of great significance for the reception of visitors and travellers, speeches, the farewelling of parties. Important meetings or special receptions for hosting guests would be done in the wharenui and on the marae. Pātaka, elevated on one or several posts and stocked with food, allowed the marae to nourish people. Together they formed three important elements in administering the social needs of the tribe and by which the social prestige of a tribe and its mana rose or fell. Tribal structures have been, and are, based on kinship and a social hierarchy as well a strong set of values, rituals and protocols from which to govern (Te Aho, 2007). Within such arrangements, certain responsibilities and obligations to other members are created, maintained and severed (Barlow, 1994; Durie, 1994; MoekePickering, 1996).

Relative to the context that draws individuals together to share their enthusiasm or attachment to experiences of consumption (Atkin, 2004), how are modern consumer tribes bound and enriched by elements such as place, connection, welfare, obligation, status, nourishment, hierarchy and kinship as found in traditional and contemporary Māori institutions and structures (tribes)? With the advent of the internet and social media-which has allowed consumers to connect and share their preferences and dislikes with other consumers of any product anywhere and at any time- the consumer tribes stream of research still appears to be gaining traction. It is generating a greater understanding about the benefits and the value consumers derive from forming associations with other like-minded consumers, moving our understanding of consumer interactions and behaviour well beyond the interface between business and consumer. Māori knowledges offer a great source of inspiration in this regard.

Research suggests that the meaning consumers ascribe to products-and any subsequent value an individual derives from these products-are likely to evolve and be enhanced through the interaction with others within consumer tribes (Pongsakornrungsilp \& Schroeder, 2011). The ability of consumers to interconnect without traditional geographic constraints, or even the influence of the business, has major implications relating to how value is created between consumers (Finsterwalder \& Kuppelwieser, 2011; Rihova, Buhalis, Moital, \& Gouthro, 
2013), the reconfiguration of value propositions to allow for personal needs (Kacen, 2000) and the co-destruction of value (McColl-Kennedy \& Tombs, 2011; A. M. Smith, 2013).

How can Mãori knowledge change the way we understand consumers and value? The problem with this type of question is the risk of misappropriating Māori ways of knowing for a largely Western field of study; use of the consumer tribe construct might be perceived as problematic and even pejorative by some. But perhaps Māori marketers have a strategic advantage in the form of Māori knowledges to rethink how value is co-created. We would argue for research in the critical business space which acknowledges the dynamic interplay between Western and Indigenous knowledges (Love, 2017; Love \& Tilley, 2013) and in line with that kaupapa we would further maintain that Māori researchers and Māori knowledge could potentially redefine the boundaries of consumer behaviour research.

\section{Glossary}

$\begin{array}{ll}\text { Aotearoa } & \begin{array}{l}\text { Māori name for New Zealand; } \\ \text { lit., "land of the long white } \\ \text { cloud" }\end{array} \\ \text { hapū } & \begin{array}{l}\text { subtribe } \\ \text { twibe }\end{array} \\ \text { kāinga } & \text { village } \\ \text { kaupapa } & \text { way of doing things } \\ \text { mana } & \text { power, authority } \\ \text { Māori } & \text { Indigenous people of Aotearoa } \\ \text { marae } & \text { open area for discussion } \\ \text { pā } & \text { fortified village } \\ \text { pātaka } & \text { storehouse } \\ \text { tīpuna } & \text { ancestors } \\ \text { waka } & \text { canoes } \\ \text { whānau } & \text { extended family } \\ \text { wharenui } & \text { meeting house }\end{array}$

\section{References}

Armstrong, A., \& Hagel, J., III. (1996). The real value of on-line communities. Harvard Business Review, 74(3), 134-141.

Atkin, D. (2004). The culting of brands: Turn your customers into true believers. New York, NY: Portfolio.

Barlow, C. (1994). Tikanga whakaaro: Keys concepts in Māori culture. Auckland, New Zealand: Oxford University Press.

Belk, R. W., \& Costa, J. A. (1998). The mountain man myth: A contemporary consuming fantasy. Journal of Consumer Research, 25(3), 218-240. http://doi.org/bnpkgb

Bennett, A. (1999). Subcultures or neo-tribes? Rethinking the relationship between youth, style and musical taste. Sociology, 33(3), 599-617.

Bishop, R. (1996). Addressing issues of selfdetermination and legitimation in Kaupapa Māori research. In B. Webber (Ed)., He paepae korero: Research perspectives in Māori education (pp. 143-160). Wellington, New Zealand: NZCER.

Bronfenbrenner, U. (1977). Toward an experimental ecology of human development. American Psychologist, 32(7), 513-531. http://doi.org/ ff6zfz

Buck, P. (Te Rangi Hìroa). (1962). The coming of the Maori (2nd ed., repr.). Wellington, New Zealand: Māori Purposes Fund Board/Whitcombe and Tombs. (Reprinted from 2nd ed. published 1950)

Chandler,J.D., \& Vargo, S.L. (2011). Contextualization and value-in-context: How context frames exchange. Marketing Theory, 11(1), 35-49. http://doi.org/cq8xcd

Cova, B. (1997). Community and consumption: Towards a definition of the "linking value" of product or services. European Journal of Marketing, 31(3-4), 297-316. http://doi.org/ bnk4qg

Cova, B., \& Cova, V. (2002). Tribal marketing: The tribalisation of society and its impact on the conduct of marketing. European Journal of Marketing, 36(5-6), 595-620. http://doi.org/ dxngrt

Cova, B., Kozinets, R. V., \& Shankar, A. (2007). Tribes, Inc.: The new world of tribalism. In B. Cova, R. V. Kozinets, \& A. Shankar (Eds), Consumer tribes (pp. 3-26). Oxford, England: Butterworth-Heinemann. 
Currid, S. (2013). Build your tribe: The new marketing manifesto for restaurants, bars and cafés. St Albans, England: Panoma Press.

Durie, M. H. (1994). Whānaulfamilies and healthy development. Paper presented at the 5th Annual Conference of the New Zealand College of Clinical Psychologists, Department of Māori Studies, Massey University, Hamilton, New Zealand.

Finsterwalder, J., \& Kuppelwieser, V. G. (2011). Co-creation by engaging beyond oneself: The influence of task contribution on perceived customer-to-customer social interaction during a group service encounter. Journal of Strategic Marketing, 19(7), 607-618. http://doi.org/ cp33jd

Firth, R. W. (2011). Primitive economics of the New Zealand Maori. New York, NY: Routledge. (Original work published 1929)

Flood, R. L., \& Jackson, M. C. (1991). Critical systems thinking. Chichester, England: Wiley.

Giddens, A. (1984). The constitution of society: Outline of the theory of structuration. Cambridge, England: Polity Press.

Godin, S. (2008). Tribes: We need you to lead us. London, England: Penguin.

Goulding, C., Shankar, A., \& Canniford, R. (2013). Learning to be tribal: Facilitating the formation of consumer tribes. European Journal of Marketing, 47(5-6), 813-832. http://doi.org/ cgq8

Haar, J. M., \& Brougham, D. (2011). Consequences of cultural satisfaction at work: A study of New Zealand Māori. Asia Pacific Journal of Human Resources, 49(4), 461-475. http://doi. org/d4x $7 \mathrm{jx}$

Haar, J. M., \& Brougham, D. (2013). An indigenous model of career satisfaction: Exploring the role of workplace cultural wellbeing. Social Indicators Research, 110, 873-890. http://doi.org/b8kchb

Haar, J. M., Roche, M., \& Taylor, D. (2012). Workfamily conflict and turnover intentions of Indigenous employees: The importance of the whanau/family for Maori. International Journal of Human Resource Management, 23(12), 25462560. http://doi.org/fw3gpq

Holzweber, M., Mattsson, J., \& Standing, C. (2015). Entrepreneurial business development through building tribes. Journal of Strategic Marketing, 23(7), 563-578. http://doi.org/cgq9

Jackson, M. (1990). Criminality and the exclusion of Māori. In N. Cameron \& S. Frances (Eds.), Essays on criminal law in New Zealand: Towards reform? (pp. 23-34). Wellington, New Zealand: Victoria University Press.

Kacen, J. J. (2000). Girrrl power and boyyy nature: The past, present, and paradisal future of consumer gender identity. Marketing Intelligence and Planning, 18(6-7), 345-355. http://doi. org/ftwwkn

Kozinets, R. V. (1999). E-tribalized marketing?: The strategic implications of virtual communities of consumption. European Management Journal, 17(3), 252-264. http://doi.org/dhchf9

Kozinets, R. V. (2002). The field behind the screen: Using netnography for marketing research in online communities. Journal of Marketing Research, 39(1), 61-72. http://doi.org/c4k6pd

Kozinets, R. V. (2006). Click to connect: Netnography and tribal advertising. Journal of Advertising Research, 46(3), 279-288. http://doi.org/fjrhd7

Kuntz, J. R. C., Nāswall, K., Beckingsale, A., \& Macfarlane, A. H. (2014). Capitalising on diversity: Espousal of Māori values in the workplace. Journal of Corporate Citizenship, 55, 102-122. http://doi.org/bd99

Logan, D., King, J., \& Fischer-Wright, H. (2008). Tribal leadership: Leveraging natural groups to build a thriving organization. New York, NY: Harper Collins.

Love, T. R. (2017). Māori values, care and compassion in organisations: A research strategy. Paper presented at the 33rd European Group for Organizational Studies Colloquium, Copenhagen Business School, Denmark.

Love, T., \& Tilley, E. (2013, December). Temporal discourse and the news media representation of indigenous-non-indigenous relations: A case study from Aotearoa New Zealand. Media International Australia, 149, 174-188. http:// doi.org/cgrb

Luhmann, N. (1982). The world society as a social system. International Journal of General Systems, 8(3), 131-138. http://doi.org/d7t4dt

Maffesoli, M. (1996). The time of the tribes: The decline of individualism in mass society. (D. Smith, Trans.). London, England: Sage.

McColl-Kennedy, J. R., \& Tombs, A. (2011, June). When customer value co-creation diminishes value for other customers deliberately or inadvertently. Paper presented at the Naples Forum on Service: Service-Dominant Logic, Service Science, and Network Theory, Naples, Italy.

Metge, J. (1995). New growth from old: The whannau in the modern world. Wellington, New Zealand: Victoria University Press. 
Midgley, G. (2000). Systemic intervention: Philosophy, methodology, and practice. New York, NY: Kluwer Academic/Plenum. http://doi.org/d658qg

Mitchell, C., \& Imrie, B. C. (2011). Consumer tribes: Membership, consumption and building loyalty. Asia Pacific Journal of Marketing and Logistics, 23(1), 39-56. http://doi.org/fxjwjb

Moeke-Pickering, T. M. (1996). Maori identity within whanau: A review of literature (Working paper). Retrieved from http://researchcommons. waikato.ac.nz/handle/10289/464

O'Reilly, D. (2012). Maffesoli and consumer tribes: Developing the theoretical links. Marketing Theory, 12(3), 341-347. http://doi.org/f4b7fc

Parsons, T. (2007). An outline of the social system. In C. Calhoun, J. Gerteis, J. Moody, S. Pfaff \& V. Indermohan (Eds), Classical sociological theory (2nd ed., pp. 421-440). Malden, MA., Blackwell.

Pongsakornrungsilp, S., \& Schroeder, J. E. (2011). Understanding value co-creation in a coconsuming brand community. Marketing Theory, 11(3), 303-324. http://doi.org/ddgprc

Richardson, B. (2013). Tribal marketing, tribal branding. London, England: Palgrave Macmillan. http://doi.org/cgrc

Rihova, I., Buhalis, D., Moital, M., \& Gouthro, M. B. (2013). Social layers of customer-tocustomer value co-creation. Journal of Service Management, 24(5), 553-566. http://doi.org/ cgrd

Riley, S. C. E., Griffin, C., \& Morey, Y. (2010). The case for "everyday politics": Evaluating neotribal theory as a way to understand alternative forms of political participation, using electronic dance music culture as an example. Sociology, 44(2), 345-363. http://doi.org/bjmkxn

Ruwhiu, D., \& Cone, M. (2013). Pragmatic leadership: A return to wisdom. Journal of Management and Organization, 19(1), 25-43. http://doi.org/cgrf

Ruwhiu, D., \& Elkin, G. (2016). Converging pathways of contemporary leadership: In the footsteps of Māori and servant leadership. Leadership, 12(3), 308-323. http://doi.org/f9bgg8
Simmel, G. (1950). The sociology of Georg Simmel (K. H. Wolff, Ed. \& Trans.). Glencoe, IL: Free Press. Smith, A. M. (2013). The value co-destruction process: A customer resource perspective. European Journal of Marketing, 47(11-12), 1889-1909. http://doi.org/cgrg

Smith, L. T. (2012). Decolonizing methodologies: Research and Indigenous peoples (2nd ed.). Dunedin, New Zealand: Otago University Press.

Spiller, C., Erakovic, L., Henare, M., \& Pio, E. (2011). Relational well-being and wealth: Māori businesses and an ethic of care. Journal of Business Ethics, 98(1), 153-169. http://doi.org/dvph46

Spiller, C., Pio, E., Erakovic, L., \& Henare, M. (2011). Wise up: Creating organizational wisdom through an ethic of kaitiakitanga. Journal of Business Ethics, 104(2), 223-235. http://doi. org/b4f2n2

Tarakawa, T., \& Smith, S. P. (1894). Ko te rerenga mai o Mata-Atua, me Kurahaupo me era atu waka i Hawaiki [The coming of Mata-Atua, Kurahaupo, and other canoes from Hawaiki to New Zealand]. Journal of the Polynesian Society, 3(2), 59-71.

Te Aho, L. (2007). Tikanga Māori, historical context and the interface with Pākehā law in Aotearoa/ New Zealand. Yearbook of New Zealand Jurisprudence, 7, 10-14.

Vānninen, I., Pereira-Querol, M., \& Engestrōm, Y. (2015, October). Generating transformative agency among horticultural producers: An activity-theoretical approach to transforming integrated pest management. Agricultural Systems, 139, 38-49. http://doi.org/cgrh

Vargo, S. L., \& Lusch, R. F. (2016). Institutions and axioms: An extension and update of servicedominant logic. Journal of the Academy of Marketing Science, 44(1), 5-23. http://doi.org/ cgrj

Walker, R. (1990). Ka whawhai tonu mātou: Struggle without end. Auckland, New Zealand: Penguin. 